\title{
Manuver Robot Manual Menggunakan Pengendali PID pada Robot Manual KRAI 2018
}

\author{
Muhamad Kamaludin ${ }^{1}$, Wahyu Sapto Aji $^{2}$ \\ ${ }^{1}$ Mahasiswa Program Studi Teknik Elektro, Universitas Ahmad Dahlan, Indonesia \\ ${ }^{2}$ Dosen Program Studi Teknik Elektro, Universitas Ahmad Dahlan, Indonesia
}

\section{INFORMASI ARTIKEL}

\section{Riwayat Artikel:}

Dikirimkan 19 Agustus 2019,

Direvisi 30 Agustus 2019,

Diterima 13 Oktober 2019.

\section{Kata Kunci: \\ Kontes ABU Indonesia, Kendali PID, \\ Rotary Encoder, \\ Trial and Error, \\ Arduino-Due.}

\section{Penulis Korespondensi:}

Nama, Muhamad Kamaludin Universitas Ahmad Dahlan, Desa Melusari RT 002 RW 01, Ketapang, Kalimantan Barat, Indonesia.

Surel:

\begin{abstract}
ABSTRAK
Kontes robot ABU Indonesia mengusung tema ABU Robocon 2018 yaitu Bola Berkah. Dalam tema yang diusung, salah satu robot yang digunakan adalah robot manual yang berfungsi mengambil dan memberikan bola berkah kepada robot otomatis. Robot manual mengalami kesulitan dalam bergerak lurus ketika mengambil dan menyerahkan bola kepada robot otomatis. Ketika berada pada posisi pengambilan dan posisi penyerahan bola, robot yang menggunakan roda omniwheel tidak berada pada posisinya karena terdapat kelembaman. Penerapan Pengendali PID (Proporsional-Integral-Derivatif) yang mendapatkan nilai koreksi dari sensor Rotary Encoder merupakan salah satu solusi yang tepat untuk diimplementasikan pada robot manual. Dengan menggunakan Metode trial and error, PID yang dikembangkan dapat membuat pergerakan robot manual menjadi lebih efisien dan lebih mudah saat dikendalikan oleh operator. Robot Manual menggunakan mikrokontroler Arduino-Due. Hasil pengujian penerapan pada sistem menghasilkan akurasi gerak lurus robot sebesar $60 \%$, ketepatan posisi mencapai $88 \%$ dengan menggunakan 50\% kecepatan putar motor dan akurasi ketepatan posisi mencapai $75 \%$ dengan menggunakan $100 \%$ kecepatan putar motor.

The ABU Indonesia robot contest carries the ABU Robocon 2018 theme, Blessing Ball. In the theme, one of the robots used is a manual robot that functions to take and give a blessing ball to the automatic robot. Manual robots have difficulty in moving straight when taking and handing the ball to an automated robot. When in the taking position and the ball handover position, the robot that uses the Omni wheel is not in position because there is inertia. The application of PID (Proportional-Integral-Derivative) controller which gets the correction value from the Rotary Encoder sensor is one of the right solutions to be implemented in manual robots. By using the trial and error method, the developed PID can make manual robot movements more efficient and easier when controlled by the operator. Manual Robot uses an Arduino-Due microcontroller. The results of testing the application of the system produce an accuracy of $60 \%$ straight robot motion, position accuracy reaches $88 \%$ using $50 \%$ motor rotational speed and accuracy of positioning accuracy reaches $75 \%$ using $100 \%$ motor rotational speed.
\end{abstract}

This work is licensed under a Creative Commons Attribution-Share Alike 4.0

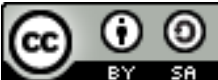

\section{Sitasi Dokumen ini:}

M. Kamaludin and W. S. Aji, "Manuver Robot Manual Menggunakan PID Pada Robot Manual KRAI 2018," Buletin Ilmiah Sarjana Teknik Elektro, vol. 1, no. 3, pp. 91--99, 2019. DOI: 10.12928/biste.v1i3.978 


\section{PENDAHULUAN}

Penggunaan Joystick pada era ini sangat banyak dijumpai. Salah satunya digunakan sebagai pengendali utama pada flight deck apabila terjadi kelelahan pada otot pilot yang dideteksi berdasarkan sinyal $s E M G$. Penggunaan joystick sebagai pengendali utama dapat memperkecil terjadinya kecelakaan [1] [2]. Selain itu dalam kontes robot Abu Indonesia, juga menggunakan Joystick sebagai pengendali robot Manual.

Kontes robot ABU Indonesia mengusung tema ABU Robocon 2018 yaitu Bola Berkah. Dalam tema yang diusung, salah satu robot yang digunakan adalah robot manual yang berfungsi mengambil dan memberikan bola berkah kepada robot otomatis. Robot manual mengalami kesulitan dalam bergerak lurus ketika mengambil dan menyerahkan bola kepada robot otomatis. Ketika berada pada posisi pengambilan dan posisi penyerahan bola, robot yang menggunakan roda omniwheel tidak berada pada posisinya karena terdapat kelembaman. Oleh karena itu diperlukan solusi untuk mengatasi masalah tersebut.

Penggunaan joystick dapat diterapkan dalam pengaplikasian sebuah robot yang menggunakan sebuah sistem kerja pengendali PID. Kendali PID atau Propotional-Integral-Derivative Controller merupakan suatu kontroler yang dapat digunakan untuk menentukan presisi dari suatu sistem instrumentasi dengan karakteristik adanya sebuah umpan balik pada sistem tersebut [3]. Pengendali PID adalah pengontrol konvensional yang banyak dipakai dalam dunia industri maupun non-industri [4]. Adapun keunggulan yang dimiliki PID adalah memiliki tiga pengendali yaitu P, I dan D yang berfungsi untuk mempercepat reaksi sistem, menghilangkan offset, dan mendapatkan energi ekstrak ketika terjadi overload atau muatan yang berlebihan [5].

Selain dapat menghilangkan offset yang dihasilkan, penerapan pengendali PID juga dapat digunakan sebagai pengatur kecepatan pada gerak putaran motor DC sehingga kecepatan putaran motor dapat kita sesuaikan dengan kecepatan yang kita inginkan. Kontroler PID dengan menggunakan metode Hand Tuning dapat menghasilkan nilai error steady state dan overshoot yang dihasilkan pada motor DC dengan toleransi kesalahan error mencapai $2 \%$ sampai dengan 5\% [6] [7]. Kendali gerak yang menghasilkan akurasi tinggi dari motor DC, beracuan dari ketidakpastian terstruktur yaitu ketidakpastian parametrik dan juga ketidakpastian yang tidak terstruktur yang berasal dari gesekan nonlinier, gangguan eksternal dan dinamika yang tidak termodelkan [8].

Robot adalah sistem yang menggantikan proses pekerjaan manusia dan memiliki kemampuan fungsional seperti manusia. Robot adalah manipulator yang dapat diprogram ulang, dirancang dan dibuat untuk memindahkan bahan, komponen ataupun sebuah peralatan dengan menggunakan peralatan khusus melalui gerakan yang bervariasi yang diprogram untuk melaksanakan berbagai jenis pekerjaan [9].

Pada Robot Abu, menggunakan robot dengan roda omniwheel yang memiliki keunggulan dalam bergerak dikarenakan memiliki kebebasan dalam bergerak yaitu pada sumbu $x$ dan sumbu $y$. Pada umumnya desain robot omni terdapat 2 jenis robot omniwheel dengan menggunakan 3 roda dan 4 roda [10].

Berdasarkan pada latar belakang, penelitian ini akan meneliti tentang robot Abu dengan roda omniwheel 4 roda yang dikendalikan Joystick. Metode yang digunakan untuk mengkoreksi posisi robot adalah pengendali PID yang dibantu oleh sensor rotary encoder. Selain itu robot juga menggunakan driver motor untuk memperbesar tegangan dari mikrokontroller ke Motor DC.

\section{METODE PENELITIAN}

Sistem penelitian yang digunakan memanfaatkan sensor rotary encoder internal yang terdapat dalam motor PG36 yang berputar setelah mendapatkan perintah atau suatu kondisi melalui joystick yang dikendalikan oleh operator robot.

\subsection{Platform Desain Robot}

Desain robot dirancang dengan sedemikian rupa dengan mempertimbangkan bahan material yang akan digunakan pada robot, seperti halnya robot industri rangka robot manual menggunakan bahan yang ringan dan kuat yaitu besi stainless. Robot memiliki 2 bagian yaitu terdiri dari bagian atas robot dan bawah robot, yang mana bagian atas robot terdapat komponen-komponen robot seperti LCD, Sistem Minimum, receiver joystick, kemudian baterai. Kemudian pada bagian bawah robot terdapat komponen seperti driver motor, motor PG36 dan roda omniwheel. Seperti tampak pada Gambar 1 kanan adalah bagian robot tampak atas dan kiri adalah bagian robot tampak bawah.

\subsection{Trial and Error Parameter PID}

Parameter PID yang digunakan diperoleh dengan cara hand tuning kemudian dikombinasikan dengan metode trial and error untuk mencari komposisi nilai PID (Kp, Ki dan $\mathrm{Kd}$ ) yang digunakan dalam program, Penggunaan metode Trial and Error memudahkan pengguna dalam menentukan titik awal gerak robot yang mengharuskan posisi robot berubah sewaktu-waktu sehingga dalam menjalankan sebuah misi atau gerak robot yang dihasilkan sesuai dengan apa yang diharapkan. parameter lain yang digunakan seperti penentuan set point dan time sampling pada robot [6]. Untuk menentukan kombinasi nilai PID (Kp, Ki dan $\mathrm{Kd}$ ) yang digunakan 
pada robot dilakukan trial and error dengan melihat bagaimana hasil dari gerak robot dan akurasi yang dihasilkan.
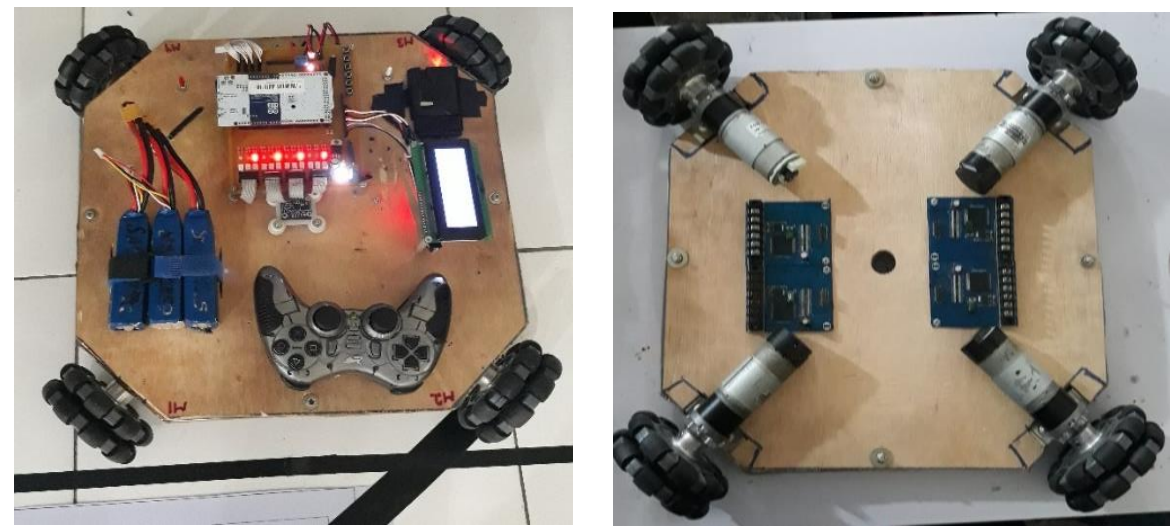

Gambar 1. Bentuk fisik robot manual

\subsection{Kinematic Robot}

Kinematic adalah sebuah teori yang digunakan untuk mengetahui sudut yang tepat untuk dibentuk setiap point pada saat membentuk posisi yang telah ditentukan sebelumnya dari end of the eefctor terhadap base [1]. Model kinemaitc pada robot yang menggunakan 4 roda dengan menggunakan omniwheel pada saat dilakukan perhitungan didapatkan nilai sudut yang berbeda-beda bentuk sudut yang didapatkan ditampilkan pada Gambar 2.

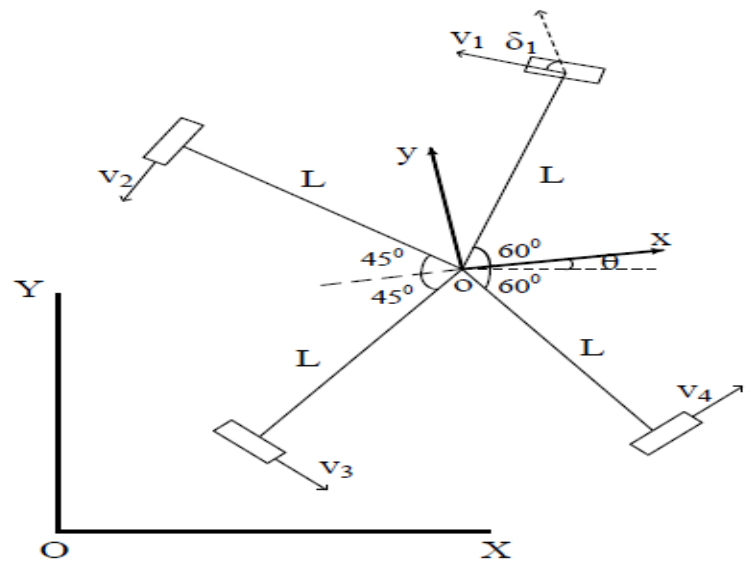

Gambar 2. sudut kinematic roda robot

Pada setiap roda robot didapatkan perbedaan antara sudut roda depan dengan roda depan lainya sebesar $120^{\circ}$ sedangkan perbedaan sudut roda belakang dengan roda belakang lainya sebesar $90^{\circ}$, sistem koordinat robot yang bergerak memiliki nilai kesalahan literal yang dihasilkan dari perbedaan sudut yang dihasilkan pada robot, bentuk kesalahan tersebut digambarkan pada Gambar 3.

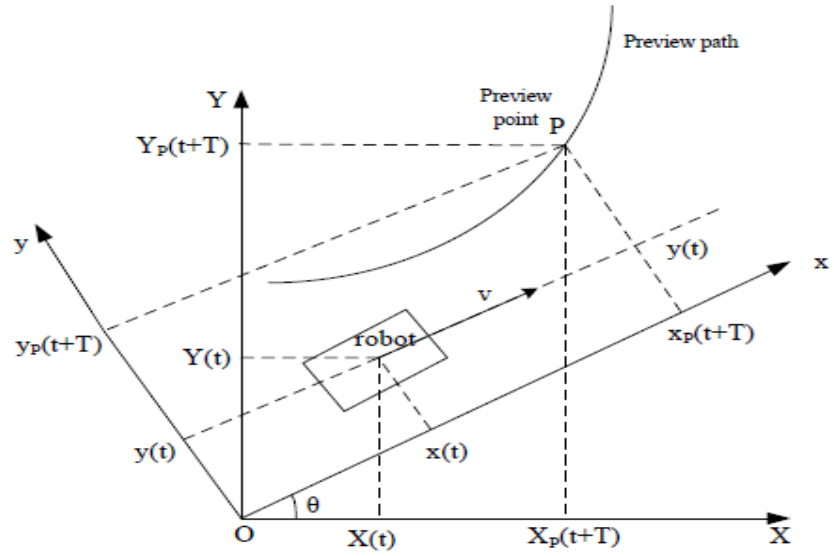

Gambar 3. Kesalahan literal gerak Robot 
Fungsi jalur robot di bawah sistem kendali absolut dapat dinyatakan sebagai $Y=Y(X)$. Pada saat di bawah sistem koordinat relatif dapat dinyatakan sebagai $y=y(x)$ hubungan antara $(x, y)$ dan $(X, Y)$ dapat didapatkan persamaan sebagai berikut,

$$
\left\{\begin{array}{l}
x=x \cos \emptyset-y \sin \emptyset \\
y=y \cos \emptyset-x \sin \emptyset
\end{array}\right.
$$

Dengan cara ini kita dapat mengubah fungsi jalur dari sistem koordinat absolut ke sistem koordinat relatif sesuai dengan arah sudut robot $\theta$ pada setiap saat [4].

\subsection{Geometric Robot}

Bagian geometric robot ini berkaitan dengan pemodelan geomatric kinematika dari bentuk robot yang menggunakan roda omnidirectional, adapun pembagian dari pemodelan kinematic dibagi menjadi dua yaitu bagian forward kinematic dan inverse kinematic. Forward kinematic berguna untuk memecahkan kecepatan sudut dari masing-masing roda kemudian untuk invers kinematic digunakan untuk memperkirakan posisi dan sudut robot bergerak yang digunakan [10]. Dalam robot simetris dengan menggunakan 4 roda omniwheel harus memiliki titik pemasangan sumbu motor pada sudut yang sama dikarenakan sudut yang terdapat pada roda sangat mempengaruhi hitungan yang akan dimasukkan pada matriks yang akan dicari hasilnya dalam program [9].

Dari bentuk persamaan maka dapat ditentukan bentuk posisi sudut motor yang digunakan, berikut ini adalah bentuk pengaturan roda yang dapat mendistribusikan kekuatan pada setiap rodanya. Bentuk yang digunakan ditunjukkan pada Gambar 4.

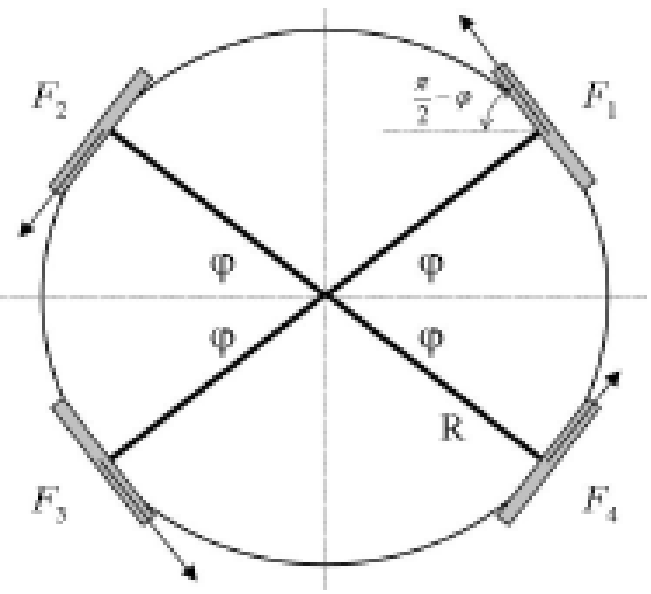

Gambar 4. Pengaturan roda dengan distribusi kekuatan yang sama

\subsection{Proses Kerja Robot}

Proses kerja robot ini secara umum ditampilkan pada diagram alir yang ditampilkan pada Gambar 5. Dari bentuk diagram alir yang digunakan terdapat 3 tahapan yang terjadi dalam robot:

1. Pergerakan motor pada robot manual ditentukan oleh perintah joystick.

2. Nilai error ditentukan dari sensor rotary encoder yang terdapat pada PG36.

3. Nilai PID yang dihasilkan pada Arduino-Due dipengaruhi present value dan set point.

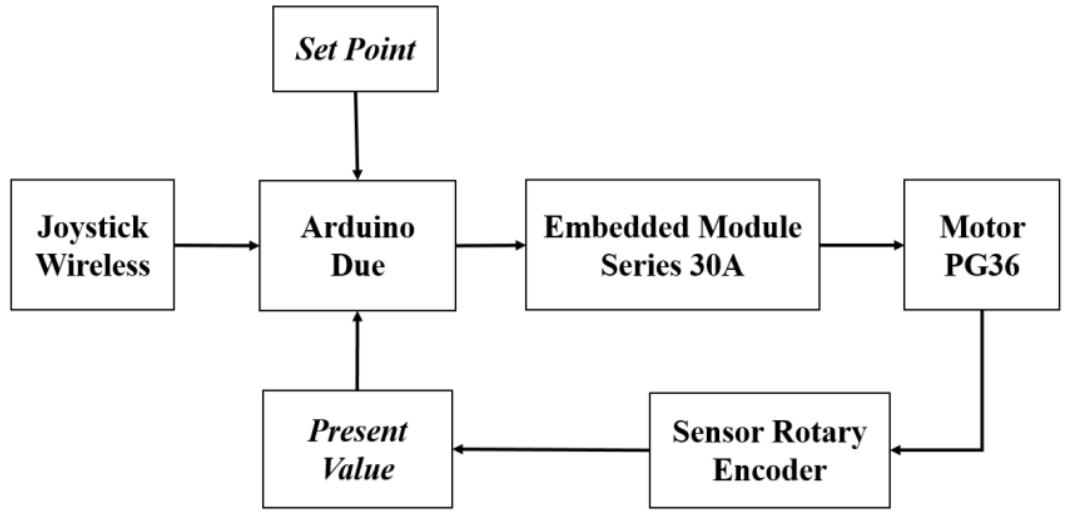

Gambar 5. Diagram alir robot manual 
Setelah dibuat diagram alir pada Gambar 5 kemudian dapat dibuat flowchart keseluruhan sistem yang digunakan pada robot yang terdiri dari sub-sub sistem yang saling terhubung sehingga dapat saling mempengaruhi hasil keluaran. Penyusunan flowchart bertujuan untuk mempermudah dalam melakukan perancangan sistem, merancang program yang akan digunakan dan kemudian memperbaikinya ketika terjadi kesalahan dalam sistem sehingga sistem dapat berjalan seperti yang diharapkan. Flowchart proses sistem dari awal sistem bekerja hingga selesai ditunjukkan pada Gambar 6.

Keterangan pada Gambar 6 adalah sebagai berikut. Pada bagian awal robot menginialisasi semua variabel yang digunakan program termasuk di dalamnya adalah Inisialisasi nilai parameter pengendali P, I, dan D. Setelah itu robot melakukan pengecekan apakah robot terkoneksi dengan joystick atau tidak. Jika robot terkoneksi dengan joystick, maka robot akan membaca data joystick. Setelah diperoleh data dari joystick, robot akan menghitung nilai pengendali P, I, dan D kemudian nilai tersebut akan digunakan sebagai nilai koreksi kecepatan Motor DC.

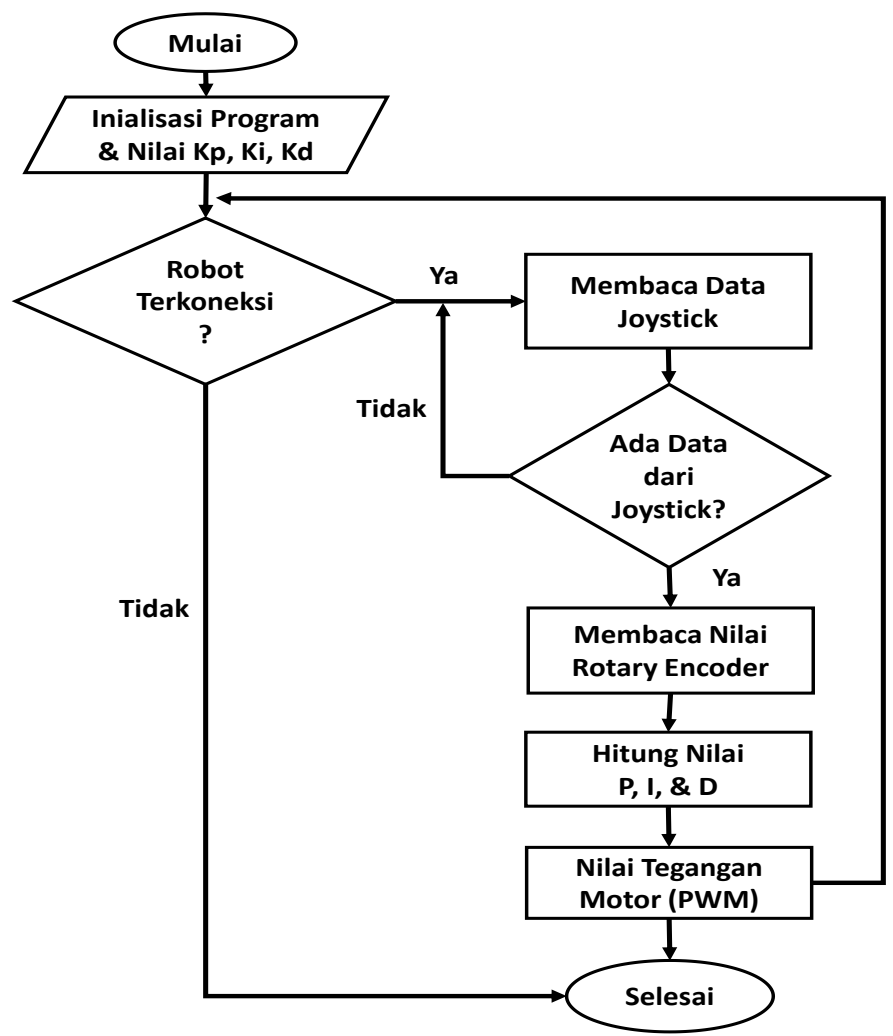

Gambar 6. Flowchart program robot

\subsection{Pembacaan nilai Rotary Encoder}

Program robot yang menggunakan software Arduino IDE dalam pembuatan program dengan menggunakan bahasa $\mathrm{C}$ bertujuan untuk mempermudah dikarenakan banyak menggunakan library yang telah tersedia di dalamnya. Pada flowchart pada Gambar 6 sebelum program dieksekusi terdapat perintah untuk membaca nilai Rotary Encoder yang terdapat dalam motor PG36 pembacaan nilai tersebut bertujuan untuk mendapatkan nilai error berlebihan yang dihasilkan oleh motor kemudian akan diproses oleh PID yang terdapat dalam program, adapun bentuk listing program yang digunakan ditampilkan pada Listing 1 .

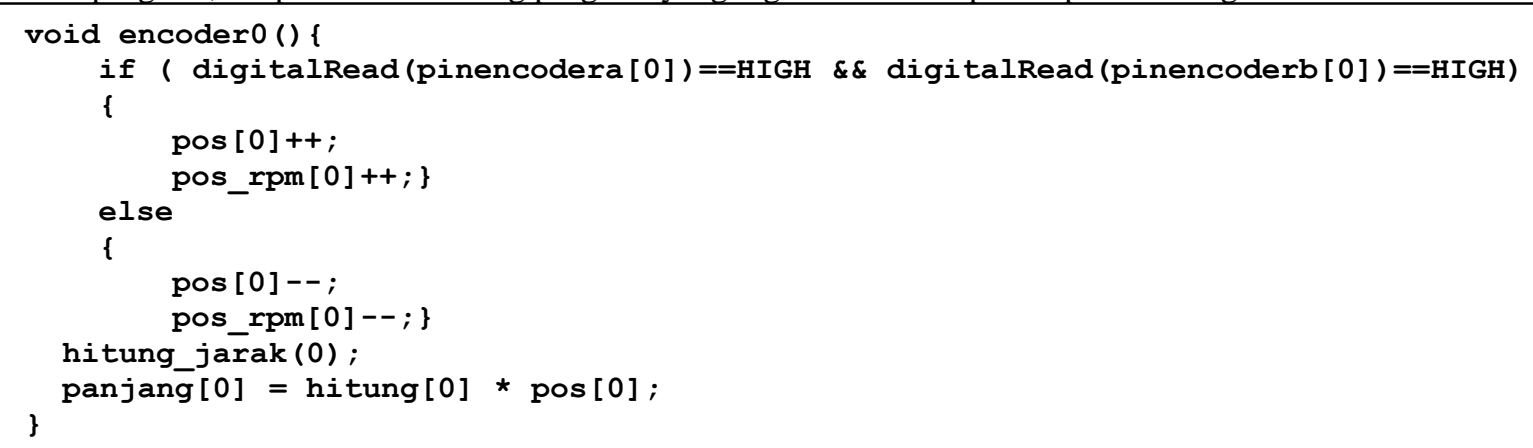

Listing 1. Program pembacaan nilai encoder 
Listing program pada Listing 1 digunakan untuk membaca nilai putaran motor, yang mana digitalRead bertujuan untuk menambah pulsa motor ketika berputar ke kanan kemudian untuk pos_rpm [0] bertujuan untuk mengurangi nilai ketika motor berputar ke kiri dan untuk mengubah satuan jarak menjadi $\mathrm{cm}$ menggunankan listing bagian panjang[0] = hitung[0] * pos[0].

\section{HASIL DAN PEMBAHASAN}

Pada penelitian yang dilakukan bertujuan untuk mengetahui cara kerja Manuver Robot Manual Menggunakan PID Pada Robot KRAI 2018 dengan menggunakan nilai Rotary Encoder Internal yang terdapat dalam motor PG36 yang kemudian diproses dengan PID menggunakan Arduino Due sebagai microprocessor processing unit dari robot manual. Setelah dilakukan pengujian didapatkan hasil sebagai berikut.

\subsection{Sistem Kerja Rotary Encoder}

Pengujian yang dilakukan pada rotary encoder bertujuan untuk menguji keakuratan nilai yang dihasilkan berdasarkan putaran motor yang telah diberi kondisi oleh operator melalui joystick, dengan kecepatan PWM yang digunakan dalam program adalah 240, diperoleh hasil keluaran yang telah diproses dengan PID seperti pada Gambar 7.

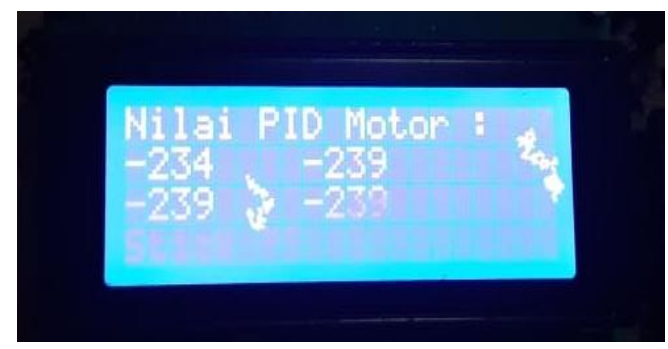

Gambar 7. Hasil nilai kecepatan dengan pengendali PID dengan kecepatan 240

Berdasarkan pada Gambar 7 didapatkan hasil keluaran -234 adalah keluaran dari kecepatan motor 1 yang mana - (minus) berarti putaran motor mengarah ke belakang atau robot menjadi bergerak mundur, kemudian putaran yang dihasilkan motor 2, 3 dan 4 adalah -239 yang mana kecepatan motor tersebut akurat atau sama. Hal tersebut dapat diakibatkan oleh keadaan motor PG yang mana sensor Rotary yang terdapat di dalamnya memiliki nilai toleransi sehingga hasil yang diperoleh tidak dapat sama semua.

\subsection{Proses Kerja robot}

Untuk mengetahui proses kerja robot pada saat bergerak lurus dengan menggunakan sistem kerja PID yang telah disatukan dengan data yang diperoleh data dari rotary encoder untuk menempuh jarak tertentu dengan menggunakan berbagai kecepatan dan menggunakan berbagai nilai PID yang didapatkan dengan menggunakan metode Trial and Error. Pengujian dilakukan pada track yang telah diberi garis lurus kemudian robot digerakkan maju diatas garis tersebut dan setelah sampai pada titik yang telah ditentukan kemudian dihitung nilai overshoot yang dihasilkan pengujian dilakukan dengan menggunakan kecepatan dan nilai konfigurasi PID yang berbeda. Gambar 8 adalah hasil pengujian gerak lurus robot.

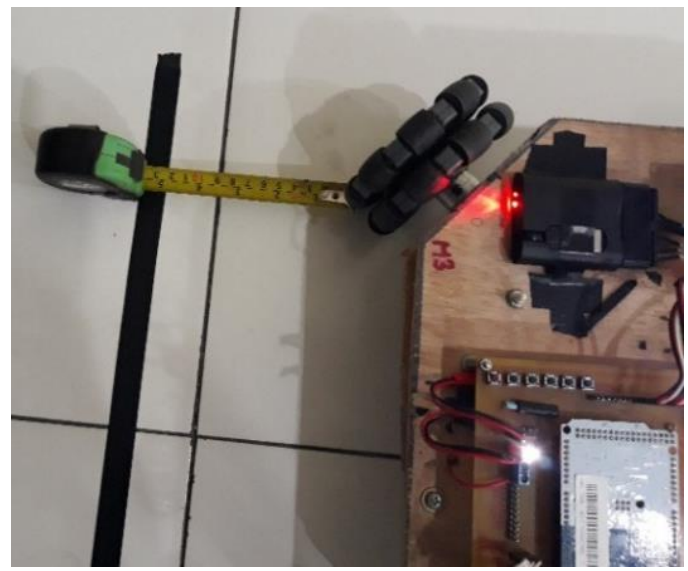

Gambar 8. Pengujian gerak lurus robot 


\section{a. Pengujian Gerak Lurus Robot}

Pada pengujian ini, robot diperintahkan untuk bergerak lurus pada lintasan yang telah ditentukan tanpa menghiraukan perintah geser kiri dan kanan, hal tersebut bertujuan untuk mengetahui keakuratan pergerakan robot dalam menempuh misi yang telah ditentukan. Gerak lurus robot sangat dipengaruhi oleh pembacaan sensor Rotary Encoder internal yang terdapat dalam motor PG36. Pengujian gerak robot menggunakan berbagai macam variasi kecepatan dan nilai PID, Kp untuk Proporsional (P), Ki untuk Integral (I), Kd untuk Derivatif (D). Nilai parameter yang pertama adalah $\mathrm{Kp}=0,001, \mathrm{Ki}=1, \mathrm{Kd}=0,01$ dan nilai parameter yang kedua adalah $\mathrm{Kp}=0,05, \mathrm{Ki}=3$, dan $\mathrm{Kd}=0,02$. Nilai tersebut dilakukan sebanyak 10 kali pengujian dengan hasil pengujian ditunjukkan pada Tabel 1 .

Berdasarkan hasil pengujian pada Tabel 1, nilai pengendali PID yang terbaik adalah pada nomor 2. Baik dengan kecepatan 50 persen dan kecepatan 100 persen, memiliki tingkat akurasi 60 persen. Dengan memperbesar nilai parameter $\mathrm{Kp}, \mathrm{Ki}$, dan $\mathrm{Kd}$, berpengaruh pada respons yang semakin cepat dan agresif yang dapat menurunkan tingkat akurasi. Oleh karena itu nilai parameter PID tidak boleh dilakukan sembarangan karena sangat mempengaruhi pergerakan robot.

Tabel 1. Hasil keakuratan pengujian gerak lurus robot

\begin{tabular}{|c|c|c|c|c|}
\hline No & $\begin{array}{l}\text { Nilai Kp, } \\
\text { Ki dan Kd }\end{array}$ & $\begin{array}{c}\text { Kecepatan } \\
\text { Putaran } \\
\text { Motor }(\%)\end{array}$ & $\begin{array}{c}\text { Rata-rata } \\
\text { Nilai Error } \\
(\%)\end{array}$ & $\begin{array}{c}\text { Keakuratan } \\
(\%)\end{array}$ \\
\hline 1. & $\begin{array}{l}\mathrm{Kp}=0,001 \\
\mathrm{Ki}=1 \\
\mathrm{Kd}=0,01\end{array}$ & $50 \%$ & $2 \%$ & $60 \%$ \\
\hline 2. & $\begin{array}{l}\mathrm{Kp}=0,001 \\
\mathrm{Ki}=1 \\
\mathrm{Kd}=0.01\end{array}$ & $100 \%$ & $2,7 \%$ & $60 \%$ \\
\hline 3. & $\begin{array}{l}\mathrm{Kp}=0,05 \\
\mathrm{Ki}=3 \\
\mathrm{Kd}=0,02\end{array}$ & $50 \%$ & $2,6 \%$ & $60 \%$ \\
\hline 4. & $\begin{array}{l}\mathrm{Kp}=0,05 \\
\mathrm{Ki}=3 \\
\mathrm{Kd}=0,02\end{array}$ & $100 \%$ & $3,1 \%$ & $40 \%$ \\
\hline
\end{tabular}

\section{b. Pengujian ketepatan posisi pengambilan}

Pengujian ketepatan posisi pengambilan dilakukan dengan cara menjalankan robot dari sebuah titik yang telah ditentukan menuju sebuah titik tertentu. Robot bergerak dengan kecepatan 100 persen dan bergerak dengan sudut hadap yang berbeda-beda. Ketepatan robot diambil dengan acuan titik $0^{\circ}$, jika semakin besar nilai error yang dihasilkan maka semakin jauh dari titik nilai yang diharapkan. Hasil dari pengujian ditunjukkan pada Tabel 2.

Tabel 2. Pengujian ketepatan posisi pengambilan

\begin{tabular}{|c|c|c|c|c|c|}
\hline No & $\begin{array}{c}\text { Posisi } \\
\text { Robot } \\
\left(0^{\circ}\right)\end{array}$ & $\begin{array}{c}\text { Waktu } \\
\text { Tempuh } \\
\text { (s) }\end{array}$ & $\begin{array}{c}\text { Kecepatan } \\
\text { Putaran } \\
\text { Motor }(\%)\end{array}$ & $\begin{array}{l}\text { Nilai } \\
\text { Error }\end{array}$ & $\begin{array}{c}\text { Keterangan } \\
\text { (Tepat/Tidak) }\end{array}$ \\
\hline 1. & $17^{\circ}$ & $7 \mathrm{~s}$ & \multirow{10}{*}{$100 \%$} & $+17^{\circ}$ & Tepat \\
\hline 2. & $14^{\circ}$ & $5 \mathrm{~s}$ & & $+14^{\circ}$ & Tepat \\
\hline 3. & $18^{\circ}$ & $8 \mathrm{~s}$ & & $+18^{\circ}$ & Tepat \\
\hline 4. & $15^{\circ}$ & $6 \mathrm{~s}$ & & $+15^{\circ}$ & Tepat \\
\hline 5. & $17^{\circ}$ & $7 \mathrm{~s}$ & & $+17^{\circ}$ & Tepat \\
\hline 6. & $23^{\circ}$ & $9 \mathrm{~s}$ & & $+23^{\circ}$ & Tidak Tepat \\
\hline 7. & $13^{\circ}$ & $5 \mathrm{~s}$ & & $+13^{\circ}$ & Tepat \\
\hline 8. & $19^{\circ}$ & $8 \mathrm{~s}$ & & $+19^{\circ}$ & Tepat \\
\hline 9. & $13^{\circ}$ & $6 \mathrm{~s}$ & & $+13^{\circ}$ & Tepat \\
\hline 10. & $21^{\circ}$ & $9 \mathrm{~s}$ & & $+21^{\circ}$ & Tidak Tepat \\
\hline \multicolumn{4}{|c|}{ Ketepatan } & $17^{\circ}$ & $80 \%$ \\
\hline
\end{tabular}


Berdasarkan hasil pengujian pada Tabel 2 dengan nilai parameter PID yang didapatkan dengan menggunakan metode trial and error, diperoleh nilai persentase ketepatan sebesar 80 persen. Tingkat keberhasilan sangat dipengaruhi oleh sensor rotary encoder. Oleh karena itu, sensor rotary encoder harus memiliki ketelitian yang tinggi. Selain itu juga diperlukan tambahan sensor rotary encoder untuk mengoreksi sensor encoder utama.

\section{c. Pengujian ketepatan posisi penyerahan}

Sama seperti pada pengujian ketepatan posisi pengambilan bola, pengujian ketepatan posisi dilakukan dengan cara menggerakkan robot dari titik pengambilan menuju pada titik yang telah ditentukan. Pengujian dilakukan dengan menggunakan kecepatan yang berbeda dan menggunakan nilai konfigurasi PID yang berbeda, hasil pengujian ditampilkan pada Tabel 3.

Tabel 3. Pengujian ketepatan posisi penyerahan

\begin{tabular}{|c|c|c|c|c|c|}
\hline No. & $\begin{array}{c}\text { Posisi } \\
\text { Robot } \\
\left(90^{\circ}\right)\end{array}$ & $\begin{array}{c}\text { Waktu } \\
\text { Tempuh } \\
\text { (s) }\end{array}$ & $\begin{array}{c}\text { Kecepatan } \\
\text { Putaran } \\
\text { Motor } \\
(\%)\end{array}$ & $\begin{array}{l}\text { Nilai } \\
\text { Error }\end{array}$ & $\begin{array}{c}\text { Keterangan } \\
\text { (Tepat / Tidak) }\end{array}$ \\
\hline 1. & $98^{\circ}$ & $17 \mathrm{~s}$ & \multirow{10}{*}{$100 \%$} & $+8^{\circ}$ & Tepat \\
\hline 2. & $84^{\circ}$ & $16 \mathrm{~s}$ & & $-6^{\circ}$ & Tepat \\
\hline 3. & $106^{\circ}$ & $17 \mathrm{~s}$ & & $+16^{\circ}$ & Tidak Tepat \\
\hline 4. & $108^{\circ}$ & $17 \mathrm{~s}$ & & $+18^{\circ}$ & Tidak Tepat \\
\hline 5. & $97^{\circ}$ & $20 \mathrm{~s}$ & & $+7^{\circ}$ & Tepat \\
\hline 6. & $84^{\circ}$ & $16 \mathrm{~s}$ & & $-6^{\circ}$ & Tepat \\
\hline 7. & $88^{\circ}$ & $16 \mathrm{~s}$ & & $-2^{\circ}$ & Tepat \\
\hline 8. & $112^{\circ}$ & $19 \mathrm{~s}$ & & $+22^{\circ}$ & Tidak Tepat \\
\hline 9. & $82^{\circ}$ & $16 \mathrm{~s}$ & & $-8^{\circ}$ & Tepat \\
\hline 10. & $95^{\circ}$ & $17 \mathrm{~s}$ & & $+5^{\circ}$ & Tepat \\
\hline \multicolumn{4}{|c|}{ Ketepatan } & $5,4^{\circ}$ & $70 \%$ \\
\hline
\end{tabular}

Berdasarkan hasil pengujian pada Tabel 3, ketepatan posisi penyerahan dengan menggunakan nilai konfigurasi yang berbeda dan menggunakan kecepatan yang berbeda-beda, didapatkan persentase keakuratan 70 persen.

\section{KESIMPULAN}

Berdasarkan penelitian yang telah dilakukan, telah berhasil mengembangkan sistem kendali pada robot manual KRAI 2018 yang digunakan dengan judul Manuver robot Manual Menggunakan PID pada Robot Manual KRAI 2018 dan dapat disimpulkan sebagai berikut. Telah berhasil mengembangkan kendali robot pada robot manual KRAI 2018 dengan menggunakan PID dengan menggunakan sensor Rotary encoder internal. Dari hasil penelitian gerak lurus robot dengan menggunakan trial and error dengan menggunakan konfigurasi PID yang berbeda didapatkan tingkat akurasi yang bervariasi yaitu 40\% sampai dengan 60\%. Hasil penelitian robot dalam pengujian ketepatan posisi dengan menggunakan metode trial and error dengan menggunakan nilai konfigurasi PID yang berbeda didapatkan akurasi yang berbeda yaitu $75 \%$ sampai dengan $88 \%$. Untuk prospek pengembangan sistem kendali yang lebih baik disarankan menggunakan Rotary Encoder eksternal untuk mendapatkan nilai yang lebih stabil pada gerak robot tersebut.

\section{UCAPAN TERIMA KASIH}

Sampaikan ucapan terima kasih kepada editor dan reviewer atas segala saran, masukan dan telah membantu dalam proses penerbitan naskah. Ucapan terima kasih juga ditunjukkan kepada pihak-pihak yang telah mendukung penelitian dan memberikan bantuan moral dan material. 


\section{REFERENSI}

[1] I. A. Sucan and L.E. Kavraki. "A Sampling-Based Tree Planner for Systems with Complex Dynamics," IEEE Transactions on Robotics, vol. 28 no. 1, pp. 116-131, 2012. doi: 10.1109/TRO.2011.2160466

[2] Z. Yang, Z. Li, L. Song, Q. Wu, and S. Fu, "Evaluation Research of Joystick in Flight Deck Based on Accuracy and Muscle Fatigue," in Engineering Psychology and Cognitive Ergonomics, D. Harris, Ed. Cham: Springer International Publishing, 2014, pp. 428-436. doi: 10.1007/978-3-319-07515-0_43

[3] A. Ma'arif, H. Nabila, Iswanto and O. Wahyunggoro, "Application of Intelligent Search Algorithms in Proportional-Integral-Derivative Control of Direct-Current Motor System." Journal of Physics: Conference Series. Vol. 1373. No. 1. IOP Publishing, 2019. doi: 10.1088/1742-6596/1373/1/012039

[4] S. B. Suharto, Purwanto and G. D. Nusantoro, "Sistem Navigasi Wall Following Robot KRPAI Divisi Berkaki Menggunakan Kontroler PID,” Jurnal Mahasiswa TEUB, vol. 1, no. 1, 2015. Online

[5] V. Nyorendra, G. D. Nusantoro, and E. Yudaningtyas, "Aplikasi Kontrol PID Untuk Penganturan Putaran Motor DC Pada Alat Pengepres Adonan Roti (Screw Coveyor)," Jurnal Mahasiswa TEUB, vol. 2, no. 2 , 2014. Online

[6] R. Alghoffary, Purwanto, and B. Siswoyo, "Sistem Pengaturan Kecepatan Motor DC Pada Alat Ekstrator Madu Menggunakan Kontroler PID,” Jurnal Mahasiswa TEUB, vol. 2, no. 2, 2014. Online

[7] S. Agustina and N. Nalapranam, "Analisa Motor Dc (Direct Current) Sebagai Penggerak Mobil Listrik." Jurnal Mikrotiga, vol. 2, no. 1, 2015. Online

[8] H. P. Siregar, Mekanika Robot Berkaki, Yogyakarta: Graha Ilmu, Cetakan pertama, 238 halaman, 2012.

[9] S. Syam, "Perancangan Robot Line Follower Menggunakan Omniwheel Berbasis Mikrokontroler BS2P40," Diploma thesis, Universitas Komputer Indonesia, 2011. Online

[10] Dong-Sung Kim, Wook Hyun Kwon, and Hong Sung Park, "Geometric Kinematics and Applications of a Mobile Robot," International Journal of Control, Automation, and Systems, vol. 1, no. 3, September 2003. Online

\section{BIOGRAFI PENULIS}

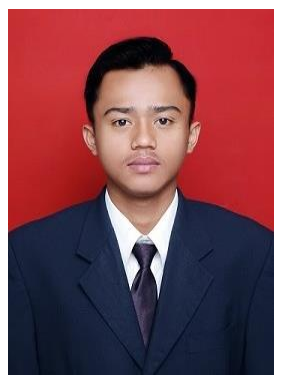

\section{Muhamad Kamaludin}

Penulis 1 adalah mahasiswa program studi Teknik elektro, Universitas Ahmad Dahlan

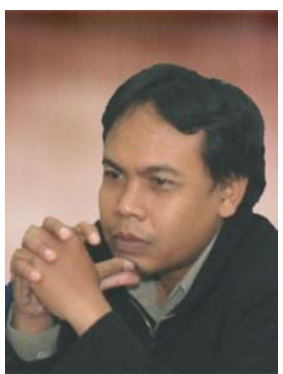

\section{Wahyu Sapto Aji}

Penulis 2 adalah dosen program studi Teknik elektro, Universitas Ahmad Dahlan. 